\title{
A Theological Perspective on the Socio-historical Grounds for Gender Disparity in the Nomiya Church
}

\author{
Samuel Otieno Sudhe ${ }^{1}$, Sussy Gumo ${ }^{1, *}$, Crispinous Iteyo $^{2}$ \\ ${ }^{1}$ Department of Religion, Theology and Philosophy, Maseno University, Kenya \\ ${ }^{2}$ Department of Peace and Conflict Studies, Masinde Muliro University of Science \&Technology, Kenya
}

Copyright $(\subset 2015$ by authors, all rights reserved. Authors agree that this article remains permanently open access under the terms of the Creative Commons Attribution License 4.0 International License

\begin{abstract}
Rites of passage are a universal phenomenon marked by transitions during major life changes. In the Nomiya Church (NC) circumcision and baptism as religious rites of initiation are simultaneously performed on the male infant on the eighth day after birth whereas the female infant gets baptism only but on the fourteenth day. The practice of simultaneous baptism and circumcision is hereby referred to as a double rite of passage. This double rite of passage in the $\mathrm{NC}$ for the male members apparently gives the male an edge over the female. The double rite of passage is connected to the purification rite of the mother after birth which demands that she is confined. The NC, the first African Initiated Church (AIC) in Kenya started among the Luo people, a community that traditionally did not practice circumcision. The socialization of the Luo community entrenched male domination and leadership while encouraging female submission. Specifically this paper explores the socio-theological grounds for gender disparity in the NC. Gender disparity in the NC is a product of various aspects of the worship and practice that exclude women from active religious participation. This system of social structures and practices manifests in a social environment where men dominate and oppress women. This study argues that the instances of gender disparity in the $\mathrm{NC}$ are connected directly or remotely to the double rite of passage.
\end{abstract}

Keywords Theology, Gender Disparity, Covenant, Double RITE, Nomiya Church, Leadership

\section{Introduction}

This study investigated the socio-theological context that explains the gender disparity in the NC.

Circumcision and baptism are religious rites of passage and their concurrent performance on the male infant on the eighth day after birth is hereby referred to as the double rite of passage. The paper explored the implications of the double rite of passage on the male members of NC. The double rite of passage apparently excludes the female members and is a clear indication and a source of gender disparity. Whereas the male infants are baptized and circumcised on the eighth day, the female infants are baptized on the fourteenth day and miss out completely on any other rite that would be the equivalent of circumcision (Kitap Lamo Mar Nomiya [1,p51]).

The double rite of passage is tied to and connected to the purification rite of the woman after birth (Lev. 12:4; Milgrom [2,p748]). Due to the female biological condition manifested in the monthly blood flow during the menses and also during the period immediately after child birth women in the NC are regarded as mogak (polluted) on these occasions. Women for the reasons of being mogak are excluded from leadership roles and from certain religious spaces. Ndeda[3,p12] on one hand argues and attributes the exclusion of women from active religious participation to that system of social structures and practices in which men dominate, oppress and exploit women while on the other hand to the belief that female sexuality contaminates and pollutes. Ndeda [3,p12] argues further that women sexuality needed periodic purification and the case in point is after childbirth where a woman was confined for a period of either thirty three days or sixty six days from the day of baptism depending on the sex of the child. While this coincides with the Jewish tradition of purification the choice and practice of the fourteenth day of baptism in the NC can be argued to be an innovation.

The fact that the male go through the double rite of passage of baptism and circumcision apparently gives them an edge (superiority and authority) over their female counterparts who only go through baptism. The socio-theological genesis for gender disparity may be traced back to the system of social structures and practices that exclude women from active religious participation. In this social environment men dominate, oppress and exploit women while the belief that female sexuality contaminates and pollutes is commonplace Ndeda [3, p12]. The idea that the monthly menstrual period is held as contaminant particularly by the male adherents has been pushed as the 
main reason for denying women leadership roles in the NC. It is well understood that a woman who happens to be in her periods is technically excluded from attending the church service and for this reason men are of the opinion that women cannot just lead the worship service.

The state of ritual impurity in the $\mathrm{NC}$ is majorly associated with women and particularly with the women sexuality and to a minor extent to men; especially in the death of a spouse. Bishop Engineer Olali [4,p98] supporting the NC stand on ritual impurity says "The understandable fact of most women being 'unclean' almost monthly is not a creation of Nomiya Church and if the Bible defines this restriction, it is not for Nomiya Church to vary it as a practice." Added to this is the common reading of the Genesis 2 creation story which connotes inferiority and subordination of the female gender because Eve is said to have come from Adam. The Gen. 1 story on the other hand is according to Kayonga [5, p137] a crystal clear indication of the fundamental equality of the sexes, each is the image of God. These patriarchal tendencies that lead to repressive domination of male in societies must be the reason behind the double rite of passage in the $\mathrm{NC}$ and by and large the gender disparity that tips the scale on the male gender.

\subsection{Socio-historical Context of the Jews}

Circumcision and baptism are religious rites of passage in the religious communities that practice them. The covenant of circumcision in the Old Testament (OT) is taken to be at the center of the spiritual union of Israel and Yahweh (Gen. 17:10[6]). Although circumcision was widely practiced in the ancient Near East, from its inception the covenant of circumcision stood out as distinct and different from the cultural practices of the neighboring Semitic tribes (Dosick [7, p286] ). The narrative in Genesis chapter 17 can be said to be the sole Biblical account of the origin of the rite of circumcision in Israel. Abraham, together with all the males in his household, were circumcised as a sign of God's covenant with him and subsequently all male infants were to be circumcised on the eighth day after birth. Marshall, et.al $[8, \mathrm{p} 204]$ argues that from that origin circumcision was integrated into the Mosaic system in connection with the Passover (Ex. 12:44[9]) and was continued throughout the OT (Jer. 9:25-26[10]). Every succeeding Jewish generation for about 4000 years has circumcised their male children on the eighth day after birth.

Although circumcision had long been in use as a religious rite among the Jews, it was abandoned at an early date by nearly the whole of the Christian Church (Cross F.L. \& Livingstone E.A. (Eds), 11,p353). This decision was arrived at the very first council of the Christian church that resolved that physical circumcision be abolished as a necessary sign of belonging to God's covenant people (Acts 15:1-6)[12]; O'Donovan [13,p236]). Consequently, O'Donovan [13] concludes that in the New Testament, the ritual of physical circumcision has been replaced with the ritual of water baptism as the sign that one has become a member of God's covenant people. Vanhooozer, K. Bartholomew, C. Treier, D.\& Wright, N. ([14:117]) concurs noting that baptism effects a once-for-all recapitulation of the believers own life and thus replaces circumcision as the effectual sign of membership into the covenant community. Baptism is regarded as the sacramental rite which admits a candidate to the Christian Church, irrespective of gender, age or colour (1Cor 12:13[15]).

Baptism symbolizes the washing away of old life and Jesus in his teaching insisted that one must be born again: 'No one can enter the kingdom of God without being born of water and the Spirit (John 3:4-5[16]). Jesus himself was baptized by John the Baptist in the river Jordan (Matt.4: 13-17[17]). Baptism in the Early Church followed a three year period of study and participation in the life of the community, prayer and fasting, after which often in the dark early Easter morning the candidates would strip naked and be baptized by total immersion (Placher [18,p184]). Unlike Jewish circumcision which is male specific and was performed on the eighth day after birth, baptism is universal and is not tied to a specific time; it could be done during Easter, Pentecost, Epiphany, and at Christmas or any other time. Baptism could also be administered by any Christian in case of imminent danger of death (Cross et al 11,p150).

Baptism in the church today seems to take on a new spiritual meaning as circumcision of the heart. In the epistle to the Romans, Paul argues that "...real circumcision is a matter of the heart -it is spiritual and not literal" (Rom.2:29[19]). It is therefore regarded as a new covenant. The idea of the new covenant comes from Jesus' reference to his blood in the formula of consecration as "the blood of the new covenant" (Matt. 26:28, Mk 14:24[20]). The crucifixion of Christ is taken to be the most important element of the new covenant. Accordingly Migliore (21,p282) defines Christian baptism as the sacrament of initiation into life in Christ.

In the "Great Commission" of Jesus the disciples are expected to participate by making disciples of all nations through baptizing and teaching them (Matt. 28:18-20; cf Mk 16:15-18; Acts 1:8; 2 Cor. 5:18-20[22]). The initiates, according to Paul have received spiritual circumcision, for example that done by Christ and not human hands ( $\mathrm{Col}$ 2:11[23]). Consequently, faith in Christ is understood to be of greater significance than circumcision or uncircumcision (Gal. 5:6[24]). Migliore ([21,324]) notes that the church has often been seen as God's people of the new covenant that has superseded the election of Israel under the old covenant ( $\mathrm{cf}$ Vanhooozer et al [14,p116]). Further, Paul notes that the cross is the way of entering the covenant and there is no distinction between Jew or Greek, slave or free, male or female - all are one in Christ (Gal 3:28[25]). In this regard baptism is seen as giving Christianity its universal and missionary outlook. As McGrath [26,p520] says, "In Christian theology baptism is seen as the Christian equivalent of circumcision."

From the foregoing it would be expected that baptism would be the central rite of passage in Christianity. However, 
right from the New Testament times the possibility of both was cited in the conversion of the Gentiles. The Jews, the first converts to Christianity had imposed circumcision on the Gentile converts as a pre-requisite to their admission to the Christian faith (Acts 15:1-7[27]). This scenario gave rise to the Jerusalem Council of AD 49. Anderson [28,p88] notes that those Gentiles who chose to follow the religion of the Jews were required to be circumcised and baptized and also to keep the whole Law of Moses. The practice witnessed in the early Church is an early example of the double rite of passage.

\subsection{Socio-historical Context of the Luo}

In many African communities, circumcision as the rite of passage introduced the candidate to adult life (Mbiti, [29,p122]; Mugambi, [30,p194]). Mugambi [30,p122] defines the term rite of passage as referring to those rituals which a community arranges to mark the transition of individual members from one stage to the next. Further, Mbiti [29,p122] notes that the rites of passage were understood as the means through which an individual is made aware and continually reminded of his responsibility as a member of his community.

This study is justified on the premise that the prescription of circumcision by Johanna Owalo the founder was strange to the Luo people who were members in the inaugural congregation. The Luo puberty rite of passage nak involved the removal of the six lower front teeth and was performed on both the male and female members of the society. The Luo community is referred to as the Southern Luo and they are people of the Nilotic Origin. The name Luo is perhaps the oldest name of the people often referred to as Nilotic people and is the name of the language spoken by groups in the Sudan, Ethiopia, Congo, Uganda, Kenya and Tanzania (Ogot [31];Ogot[32] Ochieng[33] Ocholla-Ayayo [34]).

The advent of the missionary enterprise and the colonial factor introduced not only a new way of thinking but a new religious practice that somehow replaced nak. The indigenous churches arose in those areas where there was intensive contact between African culture on one hand and the colonial/missionary efforts on the other. The missionary efforts had concentrated in two areas of dense settlement now known as Central and Western Provinces (Wipper,[35,p2]; Nthamburi, [36,p16]).The majority of the indigenous churches are located in Western Kenya among the Luo and the Luhyia communities (Nthamburi, [36,p16]. Isichei $[37,243]$ concurs and notes that Christianity was spread by catechists from Uganda to Kavirondo (Nyanza) Province in western Kenya. Missions that settled to work in both Nyanza and Kavirondo were the CMS, Catholic Missions, the Seventh Day Adventists, the African Inland Missions, the Friends Mission and Church of God Mission. Consequently, the proliferation of indigenous Churches took place in an area in which the missions were well received and where the response of mission teaching was positive (Nthamburi [36,p16]).
The reason for this good reception among the Luo people (a major group in Western Kenya) could be attributed to the shared belief in a supreme being who is the source of all livelihoods. The Luo believed in the existence of a supreme being (Nyasaye) (Ogutu, [38]; Achieng, [39]). Nyasaye is the center that holds everything together; the beginning of all things and in Him all living things owe their being. The Luo culture holds that the entire universe is God's creation and that human persons were given the responsibility of taking care of all resources from God. The Luo are also the custodians of a distinct set of values, beliefs and norms which are believed to be gifts from God to the community. This understanding of God's sovereignty and the stipulations for human beings that emanate from him as he relates to them makes it possible to appreciate the covenant relationship in circumcision and baptism.

The Luo religion was the total way of life; it defined who the Luo people are (Ongong'a, [40]). The religious life defined the relationship between members of a family, members of the same clan and members of different clans. The Luo religion manifested itself in a series of ceremonies that encompassed both the corporate rites and individual rites. These elaborate rites were meant for the welfare and good of everyone, and their enduring aim was to hold the fabric of the community together. The young of the community went through a rigorous process of socialization that involved a step by step preparation of the boys and girls to acquire the responsibilities, privileges and expectations of the community ${ }^{1}$ as they journeyed towards adulthood, marriage, and parenthood (Ocholla-Ayayo, [34]; Achieng, [39]). The process of socialization among the Luo was a continuous and life-long process that is best captured in the Luo saying ngato ipuonjo nyaka ti (one is taught until s/he is old). It was the duty of all parents and the community in general to see that the children were socialized in order to grow up as good citizens who knew the Luo kinship structure and all that appertains to Luo history and life in general. The Luo system of socialization developed several stages through which the young of the community (boys and girls) received instructions. The Luo tribal institutions and organizations shaped and molded individuals through role acting and norm internalization. The main institutions that were charged with the gathering, sifting, dissemination and indoctrination of the community membership included the Siwindhi ${ }^{2}$ institution, the $\mathrm{Duol}^{3}$ institution and the Simba ${ }^{4}$ institution and the

\footnotetext{
${ }^{1}$ When a boy reaches the age of twelve,that is after pulling off of the six lower teeth $(N a k)$, his training with regard to herding cattle is complete and his father would then require him to herd the cattle alone. Besides herding the boy learns how to milk, how to remove ticks from domestic animals, how to treat various diseases and where to find good grazing ground (Ocholla-Ayayo 1976: 68).

Siwindhi may be considered as a girl's dormitory. The house belongs to a pim an old lady who has reached menopause stage and who all boys and girls may call dayo (grandmother). The Siwindhi education stresses the Luo ideologies in the form of stories, tales, songs and riddles. Boys attend the Siwindhi between the age of seven to about age thirteen or fourteen. A boy who had reached puberty was not allowed to share the same hut with the girls. After this age boys join the Simba, the boy's dormitory.

Duol is a special house set aside for the owner of the homestead. It is a place exclusively reserved for men. Women do not sit in or participate in
} 
family institution.

There were several methods through which the value systems, the beliefs, the norms, the customs of the Luo were inculcated in the young and consequently transmitted down the generational divide from one generation to another. These included for example: the songs and riddles; stories and poems, funeral dirge and dances; Proverbs and sayings (Ochola-Ayayo [34] Odinga [41, p5]). These were the property of the Luo community and were the markers that gave the community its distinctive identity and character.

The first AIC in Kenya was founded among the Luo. The $\mathrm{NC}$ which was the first AIC in Kenya was founded by Johana Owalo in 1912 (Wipper, [35]; Nthamburi [36,p 17]; Ndeda $[3, p 5])$. Being the very first AIC in Kenya, the question this study sought to answer was what aspects of this complex social, theological and political background explains the unique practice of the double rite of passage and the gender disparity in the NC.

\subsection{Conceptual Framework}

This study is based on the biblical concept of covenant. This study chooses the concept of covenant because covenant as a hermeneutical category is a powerful heuristic tool for comprehending the large sweep of the biblical message (Vanhoozer et al [14,p142]). The relationship between members of the community of faith and God is best represented in the concept of covenant (Brueggemann $[42, \mathrm{p} 65])$. The theme of the covenant in the Bible is an expression of peoplehood. The conceptual framework of covenant in this study is best summarized as 'appropriation dialogue' as it entails mutual reciprocity whereby God moves to establish a relationship with human beings and human beings in return are to respond in obedience. Vanhoozer et al[14,p143] emphasis[ is here appropriate: "If God's essential act is one of covenant making then his people's task is fundamentally to lead others into that covenant relationship and to live faithfully in terms of that covenant." God's election of human beings to be covenant partners corresponds to God's eternal love. Covenant, therefore, is a promissory relationship that is grounded on God's grace and faithfulness (Brueggemann [42, p44-45]). This relationship is best portrayed in the text of Ex. 19:3b-8:

Now if you obey me fully and keep my covenant, then out of all nations you will be my treasured possession. Although the whole earth is mine you will be for me a kingdom of priests and a holy nation.[43]

God confers upon Israel the status of royalty (a kingdom of priests and a holy nation), if only they will obey him

discussions in the duol. It is here that the teachings of important matters relating to the community are discussed. All men are expected to gather around for their evening meal, continuing with the discussion until it is time to retire to bed. The teaching of the boys also went hand in hand with the discussions concerning the affairs of the village that were in the public domain.

${ }^{4}$ Simba is generally known as boy's dormitory. Boys who had not had their lower incisors removed were not permitted to live in Simba.
(Levenson 44, p31]). The bilateral relationship between the adherents and the supernatural is manifested in the rites of passage that are the human response of obedience. Brueggemann [42, p65] argues that in covenant making YHWH signs as the God of Israel and Israel submits in obedience to the commands of YHWH. He notes that this relationship of command and obedience is definitional of Israel and is reflected in the covenant formula and promise "I will be your God and you will be my people" (Ex. 6:7; Jer. 11:4; 24:7; 30:22; Ezek. 11:20; 14:11[45]). The Abrahamic covenant is the first instance where the human beings enjoined in the covenant are to carry on their body the sign of the covenant (Gen 17:7-11[46]).

Circumcision was understood as a seal of God's choice of Abraham and his descendants. Dosick [7,p286] says that circumcision became and endures as the sign of the covenant between God and the Jewish people. The shedding of blood was a symbol of God's chosen people being united to God himself by a blood covenant (O'Donovan, [13,p235]).The concept of circumcision progressively assumes a different understanding as an event with spiritual overtones much more than a surgical operation on the flesh of the body. This seems to be what the Bible refers to as circumcision of the heart (Deut. 10:6; Col. 2:1; Jer. 4: 4, 9:26[47]) and it means being united in heart and soul to the Lord (O'Donovan $[13, \mathrm{p} 236])$.

The Old Testament seems to point to a new covenant that will be written in people's hearts (Jer. 31:31[48]). In the institution of Holy Communion, Jesus seems to refer to his body and blood as symbols of a new covenant (Mat 26:26-28[49]).Jesus then became the paschal lamb the covenant animal while the Holy Communion became the covenant meal (Marshall etal $[8,236]$ ). The command of Jesus to the new community is captured in the Great Commission (Matt 28:19-20[50]). Entering the new covenant, according to Paul, means being baptized into Christ's death and being raised with him into new life (Rom 6:3-5 c.f. Col. 2:12[51]). Placher[18,p 187] concurs saying that[baptism] welcomes us into Christian community and calls us to a Christian life.

In the New Testament circumcision of the heart seems to imply that the ritual of physical circumcision has been replaced with the ritual of water baptism as the sign of membership of God's covenant community (1Cor.7:19; Rom.6:1-4; Col. 2:11-12; Acts 2:38[52]; O'Donovan [13, 236]; Marshall et al.[8:p121]). Further, Marshall et al $[8, \mathrm{p} 121]$ notes that the circumcision made without hands also referred to as the circumcision of the heart is what mattered most. This circumcision of the heart, he says, is effected by the gift of the Spirit and it has rendered circumcision unnecessary (Gal 3:3; 5:3-5; Rom 2:28-29[53]). Marshall et al [8] concludes that the evidence of the Spirit in a person's life serves as sign and seal of the new covenant just as circumcision served for the old covenant (2Cor.3:3-6; Jer. 31:31-34;2 Cor.1:22[54]). The human response seems to be tied to repentance and is said to be sealed by baptism (Acts 2:38[55]). 
God's covenant in the New Testament proclaims the realization of the new covenant in Jesus Christ (Migliore [21, p293]). Christ's once-for-all sacrifice is God's covenant that opens human beings to blessings and responsibilities of life in the new community that serves and glorifies God. The Church is called to be a community of love and service in which all participate in an exchange of gifts given by the "gifting God" (Migliore [21, p268]). The 'appropriation dialogue' brings God and man into a covenant partnership. Human beings are consecrated and purified through baptism and circumcision for a mutual relationship with the holy God. Vanhoozer et al [14,p81]) concurs arguing that baptism described as a "spiritual circumcision" indicates participation in the new covenant in the pardoning and cleansing from sin. Faithful partnership yields blessings while violation of the covenant leads to God's wrath (curses) (Deut. 30:15-19 [56]). Marshal et al [8, p236] argues that the new covenant removes the curse of the old Sinaitic covenant by Christ.

This bilateral relationship is best demonstrated in the triangular schema outlined here below with God at the very top as He relates to man, and man to man at the bottom. Man's response yields a community that God loves and describes as Joga (my people) and which adores God and refers to him as Nyasachwa (our God). 'Appropriation dialogue' as the inclusive conceptual framework assisted this study in investigating the origins and significance of the double rite of passage in the NC. The double rite of passage can be viewed in this context as an effort by her members to participate in and appropriate the gifts from God.

\section{Research Design}

This study employed the exploratory research design. Exploratory design serves the purpose of drawing together diverse information into a unified interpretation, thus evoking ideas and insights (Kothari [57,p36]; Peter [58,p56]). The purpose involves looking at the events and activities that precipitated the double rite of passage in the $\mathrm{NC}$ and their significance at that time and how they help to explain the rites in the NC today.

\subsection{Study Area}

The study was undertaken in Rarieda District (Total Area: $798 \mathrm{Km}^{2}$-Land: $403.4 \mathrm{Km}^{2}$; Water 394.6: $\mathrm{Km}^{2}$ ). Rarieda District is one of the new districts in Siaya County of Kenya. Rarieda District was curved out of Bondo District in 2007. Rarieda District lies between $0^{0} 26^{\prime}$ to $0^{\circ} 90^{\prime}$ and longitude $34^{\circ} 10^{\prime} \mathrm{E}$ and $34^{\circ} 35^{\prime}$ E.-(Population and Housing Census, 2009). Rarieda was chosen for this study because it is the home of origin of the late prophet Johana Owalo the founder of $\mathrm{NC}$, the foundation of the first ever congregation of NC. It is also the headquarters of $\mathrm{NC}$ in Kenya and home of the immediate former Archbishop the late Gideon Charles Owalo.
Administratively Rarieda district has two divisions namely Rarieda Division $\left(178.4 \mathrm{~km}^{2}\right)$ and Madiany Division $\left(221.2 \mathrm{Km}^{2}\right)$. Politically Rarieda District also covers Rarieda Constituency.

Table 1. The size and distribution of administrative units is as below:

\begin{tabular}{|c|c|c|c|}
\hline Division & Area $\left(\mathrm{Km}^{2}\right)$ & $\begin{array}{c}\text { No. of } \\
\text { Locations }\end{array}$ & $\begin{array}{c}\text { No. of } \\
\text { Sub-Locations }\end{array}$ \\
\hline Madiany & 221.2 & 4 & 13 \\
\hline Rarieda & 178.4 & 4 & 10 \\
\hline Total land surface & 399.6 & 8 & 23 \\
\hline
\end{tabular}

Source: Rarieda District Development Plan [59]

The population figures from the national census of 2009 indicate that the District has a total population of 134558:Males 64473; Females 70085- (2009, Population and Housing Census).

The district has an average population density of 334 persons per square kilometer. Rarieda Division has a higher population density of 368 persons per square kilometer.

Table 2. RARIEDA DISTRICT POPULATION DISTRIBUTION AND DENSITY

\begin{tabular}{|c|c|c|c|c|c|}
\hline DIVISION & Area $\left(\mathrm{Km}^{2}\right)$ & Males & Females & Total & Density \\
\hline Madiany & 221.2 & 33184 & 35416 & 68600 & 306 \\
\hline Rarieda & 178.4 & 31289 & 34669 & 65958 & 368 \\
\hline Total & 399.6 & 64473 & 70085 & 134558 & 334 \\
\hline
\end{tabular}

Source: 2009, Kenya Population and Housing Census [60]

\subsection{Sampling Procedure and Sample Size}

The sample size was considered at $10 \%$ of the accessible population. Multi-stage random sampling design was used in this study. The design was a three stage sampling design. The primary sampling unit was Rarieda district. The secondary sampling unit was the dioceses. The tertiary sampling unit was the leaders and non-leaders in the eight sampled dioceses.

\subsection{Sources of Data}

Both secondary and primary sources of data were used. Primary data was obtained from the field using the research instruments of interview schedule, observation schedule, questionnaires and focus group discussions. Secondary data was obtained from international refereed journals, published and unpublished books and manuscripts, written reports from the church as well as from Kenya National Archives (KNA).

\subsection{Data Analysis}

The qualitative data collected from primary sources were first edited for accuracy and completeness. The data generated were coded and consequently the data was organized and grouped according to the patterns and themes 
related to the objectives of the study. The themes were then organized into categories that enabled the research objectives to be fully analyzed. The themes, categories and patterns were then evaluated in relation to the research questions.

\section{Instances of Gender Disparity in the NC}

Gender disparity in the NC is a product of various aspects of the worship and practice. This study argues that the instances of gender disparity in the $\mathrm{NC}$ are connected directly or remotely to the double rite of passage. Several such instances are discussed below.

From the sampled population leadership stood at $71 \%$ male whereas female in leadership was $29 \%$. For the non-leaders the female dominated at $64 \%$ while the male were $36 \%$. The actual picture is that in every NC congregation there are more female members than male members Ndeda [3,p14] concurs stating that: "Paradoxically women attended and attend church in greater numbers than men..." The ritual leaders, Bishops, priests and the shariff (the circumciser) are all male. The position now is healthier as women participation is enhanced but still women remain at the periphery of important administrative decisions and ritual decisions.

The sitting arrangement in the $\mathrm{NC}$ is ordered and very organized. Two levels are discussed here:

Sitting in the church and sitting in the night vigil (Mony). Sitting in the church can be said to be divided into three distinct areas: the raised platform area (Sunagogi), the male side and the female side. The sitting on the raised platform is specifically for clergy; who are purely male. The clergy sit facing the congregation with their back to Kibla ${ }^{5}$; In front of them are female congregation on their left and the male congregation on their right. Bishop Eng. Olali [4,p99] argues that the Sunagogi area is considered out of bounds for other categories of NC membership, that is women, uncircumcised and unclean clergy.

The Mony is that special occasion where the NC members spend the whole night in praise and worship, either in a funeral vigil or a night vigil that marks the end of the period of seclusion of a mother and her child after birth and baptism. These occasions are usually held in tents in the homes of adherents. In this set up the leaders (men only) will be seated at the front facing the congregation. Par (mats made from papyrus reeds) are laid at the feet of the leaders to allow the

\footnotetext{
5 Prayers are made with the adherents especially the male adherents kneeling down. It is important that like the Muslims the prayers are made in the direction of Kiblah. Qiblah according to Kateregga and Shenk 1993:44 "is the direction of prayer and it was changed from Jerusalem to Makkah." On the other hand the NC Constitution says: "At all times when offering supplications or prayers to Jehovah God or when conducting any service, it will, and must be strictly observed that the congregation faces the Holy Land-Middle East-better known to members of the Church as KIBLA." Churches in the NC are built in a general north easterly direction, a direction that is believed to face Kiblah. Archbishop Owalo (72) concurs with the above saying: "Kibla or Qiblah is an Arabic word which means the direction which is faced towards Jerusalem in prayer"
}

comfort of their shoeless feet. A few women will be seated on the mats with their feet stretched out before them while the rest of the congregation will be seated on chairs behind these women. This arrangement allows the congregation to easily break into song and dance which is the characteristic feature of an all-night vigil.

In the $\mathrm{NC}$ there are three occasions where members are said to be ceremonially unclean; these include a woman during her menstruation, a woman after child birth or persons handling of a dead person. One who is ritually unclean was not eligible for ritual observance with a full and complete heart. Ndeda (3,p13) confirms this arguing that women sexuality in the NC needed periodic purification. She is in error though in reckoning that the period of confinement was either thirty three days or sixty six days from the day of birth depending on the sex of the child. This period should be reckoned from the day of baptism which is the eighth day or fourteenth day for male and female infants respectively. Menstruating women are considered ritually impure because of the loss of both bodily fluid and the loss of potential life.

According to Milgrom [2,p745] a woman becomes niddah when the monthly flow begins (literally it means to "remove or separate). The word niddah, according to Milgrom [2, p745] came to refer to the menstruant herself for she too was excluded from the society by being quarantined in separate quarters. This marks the beginning of a period of sexual seclusion from her husband that lasts for a total of twelve days (Dosick, [7,p272]). Bishop Eng. Olali [4,p89]) says that women on monthly period are not allowed to enter places of worship. It is for this reason that for the NC male it is unconceivable that a woman may be ordained a minister in the church.

The ritual impurity in birth for the woman is comparable in terms of length and quality to the impurity at the time of her menstruation (Lev 12:2\&5[61]). In case of the birth of a male child it is seven days of ceremonially uncleanness while in the case of the birth of a female infant this period is doubled to fourteen days. The NC following on the Jewish prescription will circumcise and name the male infants on the eighth day while in a departure from the Jewish prescription will name the female child on the fourteenth day after birth. To successful complete her period of blood purification the mother and the newborn are to be in isolation for a total of forty days for the male child and eighty days for a female child. The infants remain with their mothers during this period of keno ${ }^{6}$ (confinement). During this period and to ensure that the total period of seclusion gives honor to God, the $\mathrm{NC}$ has brought together the prescription in Lev. 12 and those in Numbers 6 to define what it means to be set apart for God.

The woman in seclusion is to remain indoors and inaccessible to visitors. This aspect resembles the traditional Luo practice where young women and children were

\footnotetext{
${ }^{6}$ Keno also called tuo: This is the Luo word referring to the period of seclusion for infant and the mother or the period of healing for the mature initiate.
} 
forbidden to enter the house of a woman who had just given birth until her cleansing in the first ritual sex (ngado imbo nyathi $)^{7}$, on the third or fourth day depending on whether the child was female or male (Achieng [39,p87]). Household chores including cooking, drawing water, fetching firewood and even visiting the market are avoided. Items regarded as holy for example the Bible or priestly vestments are not be touched by the woman; she is not to attend any gatherings for worship (Lev 12:4[62]).She is not to attend any funeral even that of a very close relative (Num.6:6-7[63]). The father is not allowed to hold the child for fear he would introduce pollutants to the infant. The couple is expected to abstain from sex. A Polygamous marriage contributed to the success of the isolation in that it enabled the couple to observe abstinence but allowed the man fulfillment of his conjugal rights with the other wives. It assured the confined woman and child a period of uninterrupted rest.

To mark the end of the isolation three things happen: on the eve of the purification the mother and child are shaved clean as a sign of the end of the period of the vows; a night vigil (Mony) is held in the homestead; the completion of the blood purification is marked by an early morning participation of the parents and the officiating priests (only the circumcised and women who have had similar experiences in the past) in partaking the sacrificial meal. Thus the mother and her child are readmitted into the larger society. A part from a monogamous situation where the husband to some extent feels the burden associated to the confinement, for a polygamous situation seemingly it is business as usual. The confinement of women and the attendant regulation has no parallel among the Luo.

Touching the body of a dead person brings about ritual impurity. The prescription in Num. 19:11-13[64] is clear that those who touch the dead body of a human being will be unclean seven days and will be purified with the water on the third day and on the seventh day. The purification according to the NC prayer book enables the bereaved persons to reenter the community life. A widow is eligible for the leviratic marriage 70 days after the burial of her husband. The widower equally can remarry only after the seventieth day ceremony of opening the grave. The clergy are not allowed to marry a widow or a divorcee. This seems to be the only instances where a male $\mathrm{NC}$ member may be in isolation awaiting purification and re-entry into the community life.

The Luo are a patrilineal exogamous society as demanded by the normative beliefs. The rite of Marriage represents the joining of two sub-tribal groups, two families and the couple. The traditional Luo society permitted both monogamy and

\footnotetext{
${ }^{7}$ The Rite of Birth involves initiating the infant into the world through a ritual and naming ceremony. Among the Luo on the day of birth the couple ate ugali in a calabash (kuon agwata). This practice continued for three or four days until the baby was taken outside the house for the first time after birth (chieng yiego nyathi). On this day also the parents had (ritual) sex ngado imbo nyathi for the first time since the birth of the child. This was an important Luo custom that symbolized mutual regard for each other. The ngado imbo nyathi ceremony had the dual purpose of, one, setting the woman free such that other women and children could now interact with her, and two, if she were to have an extra -marital affair then the child would not be affected by sex related taboos, chira (Achieng 2001:87).
}

polygamy but the later seemed to be the preferred mode. The Luo rules provided for the acknowledgement of the order of seniority of the wives; the first wife was called Mikayi, the second was called Reru and the third was called Nyachira and all rest were called Nyi udi (Ocholla-Ayayo [34,p38]). On this basis the NC practice of polygamy is entrenched.

The missionary enterprise read and advocated that God's ideal was monogamy. Christianity taught that God created man and woman to be companion and helpers of one another (Kirwen $[65,152])$. Consequently the missionary enterprise promoted a new concept known as monogamous Christian homes (Mugambi [30,p 42]). Polygamy, according to Christian teaching is not the will of God and Christian scholars argue against it saying it is fraught with a myriad of challenges like repercussions on the economic, social and religious spheres characterized by continual fighting and wrangling among the co-wives (O'Donovan, [13,p291]; Blum, [66,p24]).

A number of Christian denominations especially in Africa read the same script differently; thereby justifying the practice of polygamy in Africa. Marriage in African societies was a status symbol; the main reason for polygamy rested in the strength in great numbers as additional wives increased the size of a man's household and additional children were a valuable economic asset (Mugambi [30:p204];Blum [66:p104-105]). Archbishop Owalo [67,p85-86]), reading the parable of Jesus(Lk.13:28-29 cf Matt.8:11-12) where Abraham, Isaac and Jacob are sitting at the banquet in heaven argues that Abraham though a polygamist gained access to heaven. For him the Almighty God offered two kinds of marriages polygamy and monogamy.

For the Luo, the primary purpose of marriage was procreation as a means to perpetuation of life and of the Luo community (Ocholla-Ayayo [34,p150]). Levirate marriage is the name of the ancient custom ordained by Moses by which when a man died without a son his surviving brother was required to take the widow so as to continue the brothers family(Deut. 25:5-10[68]). This prescription in all its detail resembles the Luo custom and the Luo Levir is known as Jater. The Luo marriages were not dissolved by death; the wife still remained the legal wife of the deceased and was expected to continue raising children to his name through a leviratic union. If on the other hand it was the wife that passed on then the wife's kinsmen or parents were to provide a girl to replace their dead daughter (Ocholla-Ayayo [34,p144]). This is the background on which the $\mathrm{NC}$ polygamy and leviratic unions is understood. The practice of polygamy and leviratic unions in the $\mathrm{NC}$ is a hybrid practice that introduces a new angle to the wide spectrum of Christian faith and practice.

Baptism of females in the NC stands distinct from that of the males in a few significant ways; it is day specific on the fourteenth day and there is no other ritual like circumcision in males. It is done in homes of parents who must be full communicant members. After baptism on the fourteenth day the infant and her mother remain in seclusion for sixty six days. The period of ritual impurity (fourteen days) as well as 
the period of blood purification (sixty six days) are all double that for the birth of a male infant (Lev12:1-8[69]). Female infants whose parents' are not full communicant members will be baptized in the church after the requisite period of blood purification for the mother has been completed; they do not go through a period of seclusion. Adult female possibly from other faith backgrounds have to be taught the Katekism and thereafter be baptized.

Leadership among the Luo people that is generally apportioned to the male gender traces its roots right from birth. The Luo custom requires that the infant remains with its mother in her house for three days if it is a female child and four days if it is male (Ndisi [70,p76]; Ocholla-Ayayo [34]; Achieng [35,p88]). Male superiority is tied to the contact time of the child with the sun. According to Ndisi [70,p76] the man's main superior position is due to his physical attributes and partly because the male have to be shown to the sun four days after birth and the female three days after birth.

The NC with the Luo patriarchal base carries this notion of superiority of the male gender into its interaction with Judaism. The NC then accepts that circumcision on the eighth day because of the shorter period of ritual impurity gives an edge to the male gender over the female gender whose period of ritual impurity is longer. This gets support in what Milgrom [2, p751] posits that the cultic inferiority of the female sex is expressed in giving the female a double 'uncleanness effect.' Consequently Archbishop Owalo $[67, \mathrm{p} 53 \& 70]$ argues that because God is the head of Christ and Christ the head of all humanity, so man is the head of the two sexes and consequently the woman has to remain in subjection to man not usurping man' place and further that the woman should keep the rank God has chosen for her.

The NC having accepted the superiority of the male gender over the female gender understands only one thing that decision making is the preserve of men. This however did not preclude the consultation of women on issues with repercussions on the family. On such instances the man may be heard saying, "We apenj orindi mondi" (Let me consult the head rest before making the decision). This headrest was a woman frequently the first wife mikayi (Ndeda [3,p4]).

The Bible has severally been used as the source and definition of social structure where gender is the basis of understanding of roles. Leadership and teaching roles were therefore viewed as the preserve of men. The NC is no exception having entrenched some of these into her general rules and regulations regarding worship; the NC men were and remain the main actors in roles of leadership and decision making, ritual leadership, preaching and teaching. Preaching is mainly the role played by the worship leaders. This role is not only denied women but the uncircumcised: Joma ok oter nyangu ok yal ekanisa mar jo Nomiya (Nomiya does not allow the uncircumcised to preach in their places of worship) (Bishop Eng. Olali [4,p92]). Similarly women are expected to be silent in the church: (Mon ok yal e kanisa) (Bishop Eng. Olali [4,p94]). Ndeda [3,p13] concurs: "Women remain seated and initiate song from this position.
Currently some may preach during Mony (All-night vigil)."

The patriarchal society has assigned women the domestic roles. Given the nature of the NC worship where feasts (sawo) accompany the rituals their women are called severally to serve at tables to ensure the visitors are well taken care of (Ndeda [3,p12]). In patriarchal societies men are the owners of land and other assets which they apportion to their families as they think best; a woman owned nothing. In the polygamous homestead the husband was the head of many households (Ndeda [3:p3]).

Right from the creation story in Genesis women have been variously regarded as subordinate and subservient. Kayonga[5,p139-140] expresses this history of discrimination saying: "First, they were not circumcised and hence could not be part of God's covenant, Next, they were subject to a series of rigid laws of "purification" by reason of their female biological condition. Finally they had been personified in Eve, with all the inferiority that implied." The notion carried forward is that they were created from the rib of man and consequently they were as it were the ones who succumbed to the trickery of the serpent (Satan) and cheated man.

The patriarchal stories and stories of other heroic Bible characters have portrayed the patriarchal tendencies. In Paul's writings several churches have found grounding for disallowing women participation in the public rituals. In the $\mathrm{NC}$ given the place of circumcision Paul is read differently; a number of the adherents are particularly disturbed about Paul's communication on circumcision. Paul is emphatic that real circumcision is a matter of the heart; it is spiritual and not literal and what counts is faith in Christ Jesus (Rom. 2:29; Gal 5:6 [71]). When it comes to those cultural prescriptions that seemingly give men the dominant position then the $\mathrm{NC}$ is fully in support of Paul (According to Paul a woman is neither permitted to have authority over man, nor to act as a teacher, but she is expected to be quiet because it was Eve who deceived Adam (1Tim 2:12-15 [72]). Women are to cover their heads as a token of their subjection (1 Cor. 11:4-5[73]). From the foregoing the NC generally is uncomfortable with Paul's view on circumcision but they are comfortable with his views on women confirming what could be referred to as a double dose of patriarchy that encouraged male superiority. This is what Ndeda [3,p13] refers to as : "patriarchal value systems borrowed from both the Luo patterns and colonial system were supported by religious beliefs of the NLC..."

Paul seems to be requiring the silence of women while in church and should they have areas that require explanation then they need to raise the same with their husbands. The Timothy text, 1Tim 2:12-15[72] is the one frequently cited in prohibiting women from using their leadership and teaching gifts. Women are not permitted to teach because they were not only formed after the man but were the ones who were deceived by Satan. The woman's place is prescribed in the law and two things are expected of her, silence and submission because it is shameless for her to dare to speak in church. Accordingly Archbishop Owalo $([67, \mathrm{p} 53])$ suggests 
that women are what they are because that is God's design that they remain submissive and subservient to men.

The mark of circumcision carried by the NC members who have gone through the rite of circumcision emphasizes a sense of corporateness into a distinct group of adherents. The circumcised are hereby considered as those carrying on themselves the mark and seal of God as members of the covenant community. As such they are regarded as accepted before God. Circumcision gives the circumcised men a special status; way above the uncircumcised men and women. For them the raised area of the church is not accessible. The centrality of circumcision comes out in the sermons during the sawo (celebrations that mark reincorporation of the woman and her child into the community after seclusion) and in the songs that pour great tribute circumcision ${ }^{8}$. This position is already experiencing a challenge from the "salvation movement ${ }^{\text {"9 }}$ which though minor at the moment is bound to grow into a major force.

The process of socialization among the Luo was a continuous and a life-long process that began at childbirth and continued until death (Ocholla-Ayayo [34]). The value systems and the customs of the Luo were inculcated in the young and consequently transmitted down the generational divide. Ndisi [70,p37] notes that a young girl learned the task of women by observing her mother. The roles of women were thus defined around the domestic chores and more importantly and of priority is the respect that must be accorded the men folk. The socialization of the boys took place in the context of the discussions concerning the affairs of the village. The boys learned rules about wars and the best way to organize cattle raids; they also learnt from elders the art of building, basketry, shield making and house thatching among many of the manly roles (Ndisi [70,p6]; Ocholla-Ayayo [34], Achieng [39]). The socialization of men prepared them for leadership roles in the society (Achieng [39,p8]).

The missionary enterprise as well as the colonialist factor had such an impact on the African cultures and the net effect was a shift in cultural values and aspirations. Christian civilization was meant to uproot the devil of ignorance, hunger, cruelty and immorality (Burgman [71]). Christianity therefore represented a superior culture that was manifested in the newly introduced institutions like schools, hospitals and was also expressed in the new practices of the Christian Church such as marriage and baptism.(Mugambi [30,p22).

\footnotetext{
${ }^{8}$ Just because the practice of circumcision was a novelty among the Luo People, the sharp sword was for a long time understood only as it related to circumcision. A number of adherents still see the sharp sword only in this manner and for them the sayings like Pand Jo-Kowalo motimo remo(the knife of the NC adherents that is covered with blood and Pand Jo-Kowalo misiayo asiaya to dhi (the knife of the NC adherents that cuts in a flash) make a lot of sense. For them salvation is through circumcision and whoever is circumcised in the flesh as the law stipulates has booked himself a place in heaven.

${ }_{9}$ The 'salvation movement' are that group in the $\mathrm{NC}$ for whom salvation through the great Easter event of the death and resurrection of Jesus Christ supersedes any other means of accessing God's salvation plan. For them the two texts Roman2:228-29 and Gal. 3:28."True circumcision is not external and physical.. is a matter of the heart- it is spiritual."'....there is no longer male or female, for all of you are one in Christ Jesus."
}

Employment for wages was introduced by the colonialists and the missionaries. This possibility encouraged men to leave their rural homes for employment in European firms. The wages were meager and this led many of the workers to be detached from their ancestral lands for long periods (Hughes [72,p97]). Women were through this dispensation rural folk who could only visit towns once in a while. Through this definition women's role as house wives and the men as wage earners was entrenched. The situation has changed drastically over the years and the number of women leaders in social economic and political spheres has increased considerably.

The arrival of missionaries and the introduction of literary education did a death blow to the Luo traditional beliefs and practices. As a result a new social, economic and political landscape was put in place (Ogutu [73,p18]). The missionary factor provided a platform on which Africans could speak the same language with the international community and could be affected equally by the socio-political, religious and economic issues on the global stage. These developments seemingly have had little impact on the NC which still projects the patriarchal tendencies.

\subsection{Discussions of the Socio-Theological Grounds for Gender Disparity in the NC}

These tendencies are discussed here below under the subheadings of patriarchy, polygamy, levirate marriage, baptism of female infants and purification after birth and leadership in the NC:

\subsubsection{Patriarchy}

Patriarchy is defined as a family, group or government controlled by a man or a group of men. Patriarchy is usually thought of as men striving to keep women in low position and men in a high one (Miles, [62,p18]). Patriarchy in the Israelite society shows the male dominance in every sphere of life: They were the land owners... which they passed on from father to son. In the legal tribunals sat the judges and the elders who were all men. The army as was the administrative bureaucracy was composed of men. Men also dominated public religious life... (Frymer-Kensky, [63,p xiii]).

The same applied to the Luo society: A woman did not belong: In her father's homestead she belonged to the father and in her marriage she belonged to her husband and after the husband's death she belonged to her sons. In her father's homestead she was considered as an outcast Ogwang a symbol of unknown abode (Ndeda [3,p4]), Her place was always outside the homestead; on death she was buried outside the homestead (Achieng [43,p119]). A woman owned nothing; Land belonged to the man but he allocated portions to his wives; if the women however deserted before bearing a male child the farms reverted to him Wilson [64:p12].

In the NC understanding, women in the church have boundaries beyond which they are strictly not allowed to step. 
They are not allowed to step on the altar area (Sunagogi). Bishop Olali [4,p97] arguing that the restrictions in the Nomiya Church are not an indication of the any form of biasness against women says: "If women are not allowed in the raised area of the church (Sunagogi), it is a restriction covering all the uncircumcised or even unclean clergy (Bishop Eng. Olali [4,p97]). Archbishop Owalo projects the same saying women are what they are because that is God's design that they remain submissive and subservient to men (Owalo [51,p53]).

\subsubsection{Polygamy}

Polygamy is one of the key issues that caused a big rift between Johana Owalo and the missionary enterprise. The Rev. Willis sadly observes that "he fights that people should go back to the polygamous marriage in accordance with the Old Testament." (Owalo [51, p27)] This issue led the Rev. Willis to call the first Maseno Church Council to hear Owalo's stand (Owalo [51,p22]). Owalo was clear in his mind that polygamy was more acceptable in the eyes of God than being engaged in an adulterous life. According to Archbishop Owalo [51.p89] Prophet Owalo challenged a colleague, David Migot at Maseno, who was being advised to send away the second wife saying: "The son of Ochuodho' ... if you send away your wife and later she returns back to you would you not have committed adultery?... Why then have they baptized you with the name David, who was a stinking polygamist?"

Monogamy in the African sense is transitory. Accordingly Kirwen [48,p152] suggests that: "Monogamy, having only one wife is merely a stepping-stone to adding other wives...Following on this it is said that all marital relationships in Africa are potentially polygynous." Polygamy became the norm because it was not only a means of expressing status in a community but a means of correcting mishaps or failure in a marriage to yield the expected potential heirs. That Prophet Owalo was right is affirmed by Mugambi [49, p100] that polygamy was potentially allowed by custom, especially if earlier marriage did not produce children, or if the children born in earlier marriage were only girls.

The prescription for polygamy in the $\mathrm{NC}$ is that men were allowed to have a maximum of four wives and particularly if they were interested in the leadership positions in the church. The NC Constitution [65, p4] says: "The Church allows polygamy but ministers of the Church would be allowed not more than four wives." This prescription tallies with the Islamic marital jurisprudence where men are allowed to practice polygyny. "Nevertheless the fact remains that the Koran permits polygyny: "You may marry two, three or four wives but not more (Huston [66,p252]).

Prophet Owalo's prescription that led to a reversal of the Christian Church's proclamation that God's design for marriage was monogamy was such a great welcome to a people whose practice from antiquity polygamy was. The fact that the Bible itself is replete with examples of heroic servants of God (Abraham, Jacob Esau, David and Solomon) who were polygamous is a strong pointer for the NC. Archbishop Owalo [51, p85] has this to say about polygamy: "But it should be realized that whenever anybody had committed sin, God who does not change could not hesitate were it that polygamy was one of the sins. Clearly the Israelites did not think, and of course God never told them, it was wrong to have more than one wife."

Archbishop Owalo [51,p85] brings a twist by citing some New Testament examples. Looking at Paul's letters (1Timothy 3:29 [67];Titus 1:6[68]) Owalo seems to justify polygamy in the eyes of God arguing that the prescription a Bishop should be a man who was faithful to only one wife may be read in some quarters to mean that other Christians could have more than wife. But probably Paul was either simply emphasizing the importance of fidelity between marriage partners or excluding from office of Bishop, men who had broken marriages or were remarried widowers.

Archbishop Owalo [51,85] argues that in making this suggestion Paul was neither discussing monogamy nor polygamy because: "polygamists caught up playing; committing adultery with other peoples wives were stoned to death." Further Owalo [51,85] argues that the polygamists who remain faithful to their marriage partners can like Abraham and other Polygamists mentioned in the Biblical story attain the Kingdom of God. Quoting from Lk.13:28-29 [69] and Mat. 8:11-12[70] among other Scriptures, Owalo $[51,85]$ proves his point that the polygamous patriarchs are in heaven and Jesus had left them there. He concludes that the fact that Abraham, Isaac and Jacob are mentioned to be in heaven, proves to us that the Almighty God offered two kinds of marriages polygamy and monogamy; polygamy cannot be a sin. He argues that had polygamy been a sin, then David a stinking polygamist would not have been accepted before God. The official position of the NC as concerns marriage according to Archbishop Owalo [51,p88] is that marriage sanctioned by society as licit is also acceptable before God especially when it has the blessings of relatives on both sides

Archbishop Owalo during our interviews on several occasions quoted Ex.21:10[71] as another text that proves that God did not only allow polygamy but gave to Moses divine instructions on how one should handle the extra wives in marriage. In taking on an additional wife the husband is expected to maintain the food, clothing and marital rights with the first wife. Archbishop Owalo [51,85-87] supports this by citing the text of Deut. 21:15[72] that is clear that the first born son of the first wife shall not be disinherited in preference to the son of the second wife who is loved.

The fact that a man given his wealth status is culturally capable of having several wives at any one time is a window that gives the male gender an edge over the female gender. As long as many women find their place and develop besides one man, as long as the concept of male gender dominance will be perpetuated. Archbishop Owalo talking about the future of the NC tied it neatly with Polygamy saying: "the $\mathrm{NC}$ has a bright future among the Luo since the Luo are potentially polygamous." 


\subsubsection{Levirate Marriage}

Marriage among the Luo was never dissolved by death. According to Ocholla-Ayayo a husband may die, but the wife still remains the legal wife of the dead man and is expected to raise children to his name through the leviratic husband who must be a close kinsman of the dead (Ocholla-Ayayo [47,144]). Levirate marriage comes from the Greek word levir that means the husbands brother; the husbands brother was obligated to marry her late brothers widow if there was no male issue (Deut 25:5-10[73]).The man who must be in the line of the brother-in-law (Yuore) provided three basic and significant services in his brother's house: protection, provision and procreation. This act of caring is what the Luo referred to as Ter. The custom of widow inheritance is manifestation of the society's desire to assure the woman of continued support and care by having a male guardian. The woman is assured that she belongs and she is indeed among her husband's kin (Kachuoge). Widowhood is a very stressful situation. Stepping in the shoe of the dead brother was therefore a moment of comfort and assurance of the widow that she was among her own people. All was not lost.

When Owalo's theology reemphasizes the care of widows in leviratic unions as one of the pillars of the $\mathrm{NC}$ it seems to be a reversal of the gains made in Christianity over the years. Priests were denied the chance of taking on widows as is clearly stated in Leviticus 21:13[74] : “... He shall marry only a woman who is a virgin. A widow or divorced woman, or a woman who has been defiled, a prostitute, these he shall not marry..."

A widow is eligible for the leviratic marriage 70 days after the burial of her husband. The Inheritance must be within the family of the deceased husband. On the third or on the seventh day after burial a purification service is done which allows the bereaved to resume normal life, work and even to attend church service. However, the widow or widower is not allowed to enter married life until after the seventieth day celebration of Lamo Mar Yawo Liel (service for 'opening' the grave).

\subsubsection{Baptism of the Female Infants}

While the scriptures prescribed circumcision for male infants on the eighth day there seems to be no direct scriptural evidence for a specified time for the baptism of the male and female infants. Circumcision is done on the eighth day after the woman has been ceremonially unclean for the first seven days. This impurity especially the menstrual flow is later connected to the acts of disobedience of God's people. Their conduct was like a woman's monthly uncleanness" (Ezek.36:17[75]). The unbecoming conduct is cleared first by a return to fellowship with God, and the ritual act of cleansing that involves the sprinkling of clean water which alludes to Christian baptism (Ezek. 36:25-26[76] cf Heb10:22[77]).

There seems to be no evidence in the scriptures of female infant baptism on the fourteenth day.

However the evidence for the fourteenth day may be gleaned from the purification rites after birth as stated in Leviticus 12:5[78] "If a woman conceives and bears a female child "she shall be unclean two weeks as in her menstruation..." To have the female get a corresponding date of naming like their male counterparts the $\mathrm{NC}$ has introduced baptism on the fourteenth day. Baptism on the fourteenth day is a novelty, that seems to be connected to the double period of ritual impurity is unique to the NC because the Bible nowhere mentions it and neither does the Jewish tradition of naming choose the fourteenth day. In contrast naming of Hebrew girls is in no way tied to the fourteenth day but is tied to the day when the Torah is read in the Synagogue (Dosick $[14,289])$. The choice of the fourteenth day as the day of baptism for female infants put forth as a doctrinal prescription of the $\mathrm{NC}$ is indeed unique.

In the Hebrew tradition the baby naming ceremony is always followed by a festive meal (Dosick [14,290]). For the $\mathrm{NC}$ yet another novelty is realized here for the celebration of the child is delayed until the mother is ritually acceptable in the community of worshippers. This celebration is done on the day that the woman is purified, the very day when the woman enters the assembly of believers after eating together with Simeon-Ka-Lawi ${ }^{10}$ (Simeon the Levite). On this day the woman and the child are welcomed by the congregation who hug and greet them and also shower them with gifts as they congratulate them.

\subsubsection{The Double Period of Impurity}

The birth of a girl like that of a boy has a period whereby the mother is considered to be ritual impure; seven days in case of a boy and fourteen days in the case of a girl. For the birth of a girl the mother's menstrual impurity is double that of the normal menstruation. Adherents did not agree on a common explanation for this variance. Quite a big proportion were convinced that Nyawiwo (a woman's post-partum blood flow) is heavier and lasts longer in the case of the birth of a female infant; while the rest concluded that these being prescriptions from God can only be appropriated through faith.

Because the prescription for circumcision for male infants on the eighth day is given under the same breath as that for the purification of a woman after the birth of a girl, then the choice of the fourteenth day for baptism of girls by the NC may find its grounding.

\subsubsection{The Double Period of Blood Purification}

The period of Blood Purification following the birth a female infant is sixty six days and this is double that

\footnotetext{
${ }^{10}$ In the Gospel of Luke 2:22-35 a fulfillment of the Law of Moses on purification brings the parents of Jesus to the Temple in Jerusalem. Here they meet Simeon, a righteous and devout man to whom the Holy Spirit had revealed that he would not see death until he came face to face with the Lord's Messiah. Simeon took the young Jesus in his arms. This is what the officiating priest in the NC does in welcoming and incorporating the new infant into the community of believers. The name Simeon Ka-Lawi is used to designate the priest who offers sacrifice in order to re-incorporate into the community life the woman and her child at the end of the period of purification.
} 
prescribed for the birth of a boy. This then means that the infant and her mother are in seclusion for a total of eighty days before the parturient may enter the sanctuary or touch anything holy( Lev. 12:4[79]). The parturient on birth of a female infant is then considered as niddah for double the period set aside for male infants. Scholars have advanced several possible reasons: some scholars argue that postnatal discharge for a female is longer; others argue that there is a biological distinction where the male embryo is completely formed in forty one days and the female in eighty one days; others argue that the cultic inferiority of the female sex is expressed in giving the female a double 'uncleanness effect.'(Milgrom [2,p750-751]). A number of the women interviewed confirmed from their experience in birthing that indeed nyawiwo was heavy and lasted for several weeks. A number of $\mathrm{NC}$ adherents were however convinced that the explanation for the disparity can only be found with God.

At the completion of the specified period in this case sixty six days from the date of baptism the woman shall present before a priest at the entrance of the Tent of meeting a burnt offering and sin offering. The sacrifice so offered by the priest was to accomplish one purpose to confirm that she is clean from her flow of blood.

\subsubsection{Leadership in the NC}

Most of the interviewed respondents agreed that ritual leadership in the $\mathrm{NC}$ is the preserve of the male gender. Following the prescription of the Bible all clergy were supposed to be from the male gender. The NC borrowing heavily from the biblical patriarchal value system emerged within a society (the Luo) that was wholly patriarchal. This double dose of patriarchal emphases ensured male domination, as well as oppression and exploitation of the women adherents in the NC. The oppression and exploitation of women is manifested in a traditional structure that dictates that a girl remains under the patronage and care of her father who hands over his role to the future husband. In such a long and protracted system of subordination women grow and accept their subservient status and their 'voicelessness' while failing to recognize and activate their potentials and God given-talents.

The hierarchy of the church is not only male dominated but almost purely male. The male adherents are the decision maker and although they are outnumbered by the female adherents in the pews they remain the leaders of the sacraments and also the administrators of the church. Given the nature of the NC worship where feasts (sawo) accompany the rituals, women are called severally to serve at tables. Ndeda [3,p12] concurs arguing that women have been excluded from the leadership roles in all public rituals for example no women officiates during ordinations and baptismal ceremonies and to date there is no female sheriff. Archbishop Owalo [51,p53] presses this point further arguing that the order of seniority of man over woman is from God and the woman should be in subjection and not usurp the man's place (1 Corinthians.11:3[80] and also Ephesians 4:6[81]).
Women's role in the church apart from leading in the praise and worship; a role that many $\mathrm{NC}$ male adherents are equally competent and always eager to perform, still maintain and carry the traditional womanly domestic chores of cooking and serving. This role of serving their men is one they do with relish, dignity and distinction because in patriarchal society from time immemorial it has remained the defined and expected role of the female gender. The NC develops in a strong patriarchal Luo society and at the same time her theological formation is based on teachings and tenets of the Jewish society that was equally grounded in Patriarchy. Accordingly Ndeda [3, p12] says this system of social structures and practices in which men dominate, oppress and exploit women was clearly replicated in the Nomiya Luo Church. ${ }^{11}$

Women in the NC who get to the Synod the highest organ of administration of the church do so as the leaders of the women wing; and even here they may meet just as women rather than attend as joint members of this major decision making organ. Women referred to as church teachers do not have an opportunity to serve the church from the altar area because that area is exclusively for men and particularly those circumcised through the $\mathrm{NC}$ religious circumcision rite. According to Ndeda [3] Women in the NC occupy and operate on a subordinate level.

It remains an undeniable fact that prohibitions that are made against women in the church ascending to leadership positions are generally tied and related to female sexuality. Female sexuality is important because of the two distinctive characteristics of women that is the fact of their menses and the fact that at certain points in life they could give birth. These two factors are believed to pollute and contaminate things they get in touch with. For this reason the NC women are expected to skip the Sunday service and are confined so as not to mix or continue with the hub and bustle of daily life. The energy that emanates from women during these two important biological instances has been used by men to curtail women's involvement in ministry.

\subsubsection{Women and other forms of employment}

The contemporary economic status of the society concomitant with level of exposure and equal education opportunities of all the genders means that women empowerment at all levels allows and gives them an equal opportunity to compete for available jobs; many a times they have an edge over their male counterparts. At the local level women leadership is now recognized in various social roles that they play as teachers, business people and as leaders in various organizations. A number of NC women adherents are so employed and their men counterparts give them the respect due to such positions. However the patriarchal nature of the Luo society still denies women leadership in the church.

The male adherents are still adamant and their point of

\footnotetext{
11 The NC was at inception called Nomiya Luo Mission, later renamed Nomiya Luo Church.
} 
departure is based on the woman's biology. They all ask how a woman in her periods can stand before a congregation, when in the first place this condition automatically excludes her from being part of the congregation. Many of the leaders however claim that women in the NC today have been given a lot of opportunities as women wing leaders, church teachers, secretaries and treasurers. Archbishop Gideon Owalo argues that women leadership is recognized and the church has allowed them to put on scarves just like the male clergy; a significant sign that their leadership role is welcome. This is a departure from their traditional role as subservient members whose role becomes significant in worship only in as far as being music leaders and domestic stewards during ceremonies.

\section{Conclusions}

Historically, the NC faith and practice has shown clear demarcation of women and men both in their roles and expectation as analyzed above. These practices that are manifested in the sitting arrangement, exclusion of women from the service because of their menses and expectation of women to serve at tables are further amplified in the other aspects of NC worship. Examples of these include: baptism and circumcision of male infants on the eighth day while female infants are baptized on the fourteenth, isolation of women and infants immediately following birth for forty and eighty days for male and female infants respectively, prescription for marriage of a maximum of four women for $\mathrm{NC}$ leaders and the acceptance and promotion of levirate marriages; the seventy days after burial of a spouse before a widow or a widower become eligible for marriage and the clear understanding that leadership is a male calling and the reducing of female members to be choral leaders. It is apparent that instances of gender disparity in the $\mathrm{NC}$ are connected directly or remotely to the double rite of passage that gives the male gender an edge over their female counterparts.

Gender disparity in the NC is a product of the Biblical prescription and the Luo socialization that ultimately gave the male gender an edge over the female counterpart. Patriarchy in the Bible coupled with that in the Luo nations affirm the superiority of the male gender. The NC is comfortable with Paul's writing in as far as he teaches on male superiority but quite uncomfortable when he teaches that circumcision of the heart is what matters most. In the NC the ritual leaders, Bishops and priest and the sheriff (the circumciser) are all male. Leadership among the Luo traces its roots right from birth, where male superiority is tied to the contact time of the child with the sun. Female infants see the sun after three days while male infants see the sun on the fourth day. Consequently all leadership roles are designed for the male.

This double dose of patriarchal emphases (from the Luo value system and from the colonial system) ensured male domination of the women adherents in the NC. The NC then accepts that circumcision gives an edge to the male gender over the female gender The NC structure argues that man is the head of the two sexes and the woman has to remain in subjection to man, because God is the head of Christ and Christ the head of all humanity. Women because of their sexuality carry the larger burden of purification and the onus of ensuring that it is carried out in its details falls on the man.

The NC mentality which is the main reason for gender disparity can be gleaned from Christopher Anguka of Atoyo Diocese[82] who said that: "the rules given by God to his people and written in black and white cannot be varied and if ever they will be varied then we need fresh instructions or a messenger like prophet Owalo to instruct us on the variation." This means that male monopolization of leadership roles is set to continue as long as the religious socialization dictates that men are by design the spiritual leaders of the NC. Women are so socialized to accept their position thereby handing over to the male the instruments of dominance and oppression.

\section{REFERENCES}

[1] Owalo CG. Kitap lamo mar Nomiya Church. Nakuru: Gesuma; 2010.

[2] Milgrom J. Leviticus 1-16: A new translation with introduction and commentary (The Anchor Bible). New York: Doubleday Publishers; 1991.

[3] Ndeda M.A.J. “The Nomiya Luo Church: A gender analysis of the dynamics of an African independent church among the Luo of Siaya" Gender, Literature and Religion in Africa: CODESSRIA Gender Series 4, Dakar, Senegal: Council For the Development of Social Science Research in Africa; 2005.

[4] Olali C.J My faith my religion:History and basic doctrine of Nomiya Church. Nairobi:Juem Agencies; 2015.

[5] Kayonga A.M.M. African women morality (In Mugambi, J.N.K.\& Nasimiyu-Wasike, A.,eds Moral and ethical issues in African Christianity. Nairobi: Initiatives p.137-151); 1992.

[6] Genesis 17:10

[7] Dosick, Rabbi W. Living Judaism: The complete guide to Jewish belief, tradition and practice, New York: HarperSanFrancisco; 1995.

[8] Marshall et al. New Bible Dictionary $\left(3^{\text {rd }}\right.$ ed). Downers Grove, Illinois: Intervarsity Press; 1996.

[9] Exodus 12:44

[10] Jeremiah 9:25-26

[11] Cross, F.L. and Livingstone, E.A. (Eds). The oxford dictionary of the Christian Church. New York: Oxford University Press; 1997.

[12] Acts of the Apostles 15:1-6

[13] O'Donovan, W. Biblical Christianity in African perspective $\left(2^{\text {nd }}\right.$ Rev.Ed.). Carlisle, UK: Paternoster Press; 1995. 
[14] Vanhoozer, K. Bartholomew, C. Treier, D. and Wright, N. Dictionary for theological interpretation of the Bible. Grand Rapids, Michigan: Baker Bookhouse Co; 2005.

[15] 1Corinthians 12:13

[16] John 3:4-5

[17] Matthews 4:13-17

[18] Placher. Jesus the savior; The meaning of Jesus Christ for Christian faith. Louisville, Kentucky: Westminster John Knox Press; 2001.

[19] Romans 2:24

[20] Matthews 26:28; Mark 14:24

[21] Migliore, D. Faith seeking understanding: An introduction to Christian Theology. $2^{\text {nd }}$ Edition. Michigan: William B. Eerdmans Publishing company;2004.

[22] Matthews 28:18-20cf Mark 1615-18; Acts of the Apostles 1:8; 2 Corinthians $5: 18$

[23] Colossians 2:11

[24] Galatians 5:6

[25] Galatians 3:28

[26] McGrath, A. E. Christian Theology: An introduction. ( $3^{\text {rd }}$ Ed.). Malden, MA: Blackwell Publishers Inc.; 2001.

[27] Acts of the Apostles 15:1-7

[28] Anderson, K. B. Church History and Theology: Theological education by extension book. Nairobi: Evangel Publishing House; 1984.

[29] Mbiti, J.S. African Religions and Philosophy. Nairobi: Heinemann; 1969.

[30] Mugambi, J.N.K. ). Christianity and African culture. Nairobi: Acton Publishers;2002.

[31] Ogot, B.A. A History of the Luo-Speaking Peoples of Eastern Africa. Kisumu:Anyange Press Lt; 2009.

[32] Ogot, B.A. Zamani: A Survey of East African History.East African Publishing House Nairobi; 1974.

[33] Ochieng, W.R. People round the lake: Kenya's people. London: Evans Brothers Limited; 1979.

[34] Ochola-Ayayo, A.B.C. Traditional ideology and ethics among the Southern Luo. Uppsala, Sweden: Scandinavian Institute of African Studies; 1976 .

[35] Wipper, A. Rural rebels: A study of two protest movements in Kenya. London; Oxford University Press. 1977.

[36] Nthamburi, Z.(1995)(Ed). From Mission to Church: A handbook of Christianity in East Africa. Nairobi: Uzima Publishing House.

[37] Isichei, E. A history of Christianity in Africa: From antiquity to the present; 1995.Grand Rapids, Michigan: William B. Eerdmans Publishing House.

[38] Ogutu, G. E. "Culture and Language in the God Talk" Robert P. Scharlemann and Gilbert E.M. Ogutu (Editors), God in language. New York: Paragon House Publishers; 1987.
[39] Achieng,' J. Paul Mboya's Luo Kitgi Gi Timbegi: A translation into English. Nairobi:Atai Joint Limited; 2001.

[40] Ongong'a, J. Life and death- A Christian/Luo dialogue: Spearhead No.78 Eldoret: Gaba Publications;1983.

[41] Odinga, O. Not yet uhuru: An autobiography. Nairobi: Heinemann Educational Books; 1967.

[42] Brueggemann W. An introduction to the Old Testament: The Canon and Christian imagination. Louisville: Westminster John Knox Press; 2003.

[43] Exodus 19:3b-8

[44] Levenson J. Sinai \& Zion: An entry into the Jewish Bible. New York :HarperSanFransisco Publishers; 1985.

[45] Exodus 6:7;. Jeremiah 11:4;24:7;30:22;. Ezekiel 11:20; 14;11

[46] Genesis 17:7-11;

[47] Deuteronomy 10:6; Colossians 2:11;Jeremiah 4:4; 9:26

[48] Jeremiah 31:31

[49] Matthews 26:26-28 Mugambi, J.N.K.. African Christian Theology: An introduction. Nairobi: Heinemann Kenya; 1989.

[50] Matthews 28;19-20

[51] Romans 6:11; Colossians 2:12

[52] 1 Corinthians 7:19; Romans 6:1-4; Colossians 2:11-12; Acts of the Apostles 2:38

[53] Galatians 3:3, 5:3-5; Romans 2:28-29

[54] 2Corinthians 3:3-6; Jeremiah 31:31-34; 2 Corinthians 1:22

[55] Acts of the Apostles 2:38 Rom 2;29

[56] Deuteronomy 30:15-18. Gal. 5:6

[57] 1 Tim. 2:12-15

[58] Kothari C.R. Research Methodology: methods and techniques. second revised edition. New Delhi: New Age International (P) Ltd.Publishers; 2004. 1 Cor.11:4-5

[59] Peter, C. A guide to academic writing. (10 ${ }^{\text {th }}$ Reprint). Eldoret: Zapf Chancery; 2010.

[60] Rarieda District Development Plan 2008-2012.

[61] Kenya Population and Housing Census, 2009.

[62] Leviticus. 11.2

[63] Leviticus 12:4

[64] Numbers 6:6-7

[65] Numbers 19:11-13

[66] Kirwen, M.C.(editor). African cultural knowledge: Themes and Embedded beliefs. Nairobi: MIAS Books; 2005.

[67] Blum, W.G. Forms of marriage: Monogamy reconsidered. Nairobi: AMECEA Gaba publications Spearhead 105-107; 1989. 1Timothy 3:29

[68] Owalo, G.C (Archbishop). The Father is Greater than I am.(Unpublished)

[69] Deuteronomy 25:5-10. Titus 1:6. Luke 13:28-29 
[70] Leviticus 12:1-8. Matthew 8:11-12

[71] Ndisi J.W.. A study in the economic and social life of the Luo of Kenya. Uppsala, Sweden: Berlingska boktryckeriet, Lund; 1974. Exodus 21:10

[72] Burgman H..The way the Catholic Church started in Western Kenya. Nairobi: Mission Book Service; 1990. Deuteronomy21:15

[73] Hughes, A.J. East Africa, Kenya, Tanzania, Uganda. Middlesex:Penguin Books; 1963. Deuteronomy 25:5-10

[74] Ogutu G.E. Ker Jaramogi is dead; who shall lead my people. Reflections on past present and future Luo thought and practice. Kisumu: Palwa Search Publishing; 1994. Leviticus 21:13

[75] Miles, C. A., Iannaccone. L.R. New man, new woman, new life: Bible studies on marriage,family and gender. Empower
International Ministries; 2010. Ezekiel 36:17

[76] Frymer-Kensky T. Reading the women of the Bible. New York: Schocken Books; 2002. Ezekiel 36:25-26

[77] Wilson, M. Change and challenge: A study of social and economic changes among Kenyan Luo. Christian council of Kenya;1964. Hebrews 10:22

[78] The NC Constitution Revised 1973. Leviticus 12.5

[79] Huston, S.. The world's religions: Our great wisdom traditions. New York: HarperCollins Publishers Inc; 1991. Leviticus 12:4

[80] 1 Cor. $16: 3$

[81] Ephesians 4:6

[82] Christopher Anguka of Atoyo Diocese. Interviewed $19^{\text {th }}$ May 2015 